\title{
PEDAGóguSJELÖltek ÚtJA AZ INKLUZÍV ISKOLA FELÉ
}

\section{VARGA ARANKA}

a Pécsi Tudományegyetem Bölcsészettudományi Karának egyetemi adjunktusa

varga.aranka@pte.hu

\begin{abstract}
A felsöoktatás rendszerében elengedhetetlen, hogy a tanár szakos hallgatók megismerkedjenek a különbözö társadalmi hátterü, kulturális hovatartozású és egyéni sajátosságokkal rendelkezö tanulók címkézésektől mentes nevelésével. Vagyis elsödleges a pedagógusjelöltek számára olyan kompetenciák kialakitása, melyek képessé teszik öket a - heterogén iskolai közegben zajló, valamint a diákok egyediségében rejlö sokszinüséget értékként elismerö, arra pedagógiailag eredményesen reflektáló - minöségi oktatási környezet megszervezésére. Mindezt a tudást összefoglalóan az inkluzív nevelés szemléletének és gyakorlatának nevezzük. Az inklúziót támogató tanári kompetenciák kialakitásának folyamata kettös: szükséges hozzá a célzott kurzusok egymásra épülö sora, valamint a felsőoktatást átható inkluzív szemlélet és gyakorlat. A következökben e két terület bemutatására kerül sor a Pécsi Egyetem vonatkozásában.
\end{abstract}

\section{Befogadás régen és most}

A Pécsi Tudományegyetem pedagógusképzésének történetében évtizedekre visszanyúlóan megjelenik az a szemlélet, mely ráirányítja a figyelmet a diákok sokféleségére, illetve az a módszertani repertoár, mely konkrét eszköztárat kínál a sokszínüség mentén kialakított pedagógiai folyamatokra. A rendszerváltást megelőző, majd az azt követő évtizedben a „Hátrányos helyzet pedagógiája” néven müködö kurzus keretében tanulhattak a hallgatók a társadalmi hátrány mibenlétéröl, a kisebbségi csoportokról és a különböző egyéni adottságokról, hátrányokról (Várnagy és Várnagy, 2000). Ugyanekkor a „kooperatív stratégiák az iskolában” mint kutatási terület és gyakorlati alkalmazás is jelen volt az intézményben (Vastagh, 1999; Bárdossy et al., 2003).

Az ezredfordulón, a nemzetközi és hazai szakirodalomban (Potts, 2003; Réthy, 2004) is megfigyelhető szemléletváltásnak megfelelően a pécsi tanárképzés is megújult a nevelésszociológiai megközelítés területén (Varga, 2010). A „hátrányos helyzet pedagógiája” kurzus helyébe az „inkluzív pedagógia” lépett, mely nem csak elnevezésében tükrözte a címkézés nélküli szemléletet, hanem tartalmában is alapvetően megváltozott (Varga, 2006). Mindez azonban csak a kezdeti lépés volt a nevelésszociológia újragondolására, hiszen a bolognai folyamattal összefüggésben nyílt igazán lehetőség a tanárképzés teljes átdolgozására. Ekkor alakult ki az az 
egyre jobban csiszolódó és nevelésszociológiai tartalmakban egymásra épülő rendszer, mely az előadásokon közvetített tudományos alapokra építve a szemináriumok interaktív feldolgozásain keresztül a terepgyakorlatig ívelően közvetíti az inkluzív pedagógia mibenlétét.

Az iskolai inklúzió témájával való első találkozás a BA képzés utolsó félévében történik, amikor a tanári alapozó képzés részeként vehetik fel a hallgatók a nevelésszociológia föbb témaköreit tárgyaló kurzust. Ezen az „Iskola és társadalom” elnevezésű kurzuson a résztvevők többek között megismerkednek a multikulturalizmus eszmeiségével, a sokszínü társadalmak együttélési stratégiáival, a különböző társadalmi hátrányok iskolai megjelenésével, a Bourdieu-i tőkeelmélet és az adleri bikulturális szocializáció elméletével, valamint a legnagyobb hazai kisebbséggel, a magyarországi cigánysággal. A kurzuson felsorakoztatott témák mindegyike a sokszínú társadalom és a sikeres iskoláztatás demokratikus joga (mint inkluzív társadalmi idea) mentén kerül elö.

A következő lépés, amikor az MA képzésbe felvételt nyert tanár szakos hallgatók a „Nevelésszociológia” tárgy keretében az alapozás során szerzett tudásukat tovább mélyítik, és önálló tudományos munkával járják körbe az iskola és társadalom inkluzivitásának lehetőségeit és gátjait. Itt még elsősorban az elméleti ismeretek dominálnak, azonban interaktív módon feldolgozva. Csak ezt követi az MA képzés végén további - egyre inkább gyakorlati jellegü - lehetőségek sora az inkluzív szemlélet elmélyítésére, és a mesterségbeli tudás kompetencia-alapú fejlesztésére.

$\mathrm{Az}$ „Inkluzív pedagógia” elnevezésű szeminárium a kooperatív tanulásszervezés sajátélményủ elsajátításával ad egy konkrét, inkluzivitást támogató pedagógiai eszközt a hallgatók kezébe, miközben - elsősorban drámapedagógiai eszközökkel dolgozza fel a diákok sokszínüségének megjelenését az iskolában. (Lásd az 1. számú mellékletet!)

További kurzus az „Inkluzív pedagógia” speciális kollégium, mely terepen zajlik: a vállalkozó hallgatók terepen - civil szervezet által müködtetett tanodában - találkozhatnak hátrányos helyzetű, gyermekvédelemben élő, roma/cigány stb. diákközösséggel. Itt próbálhatják ki „élesben” eddig szerzett pedagógiai mesterségbeli tudásukat azzal, hogy közremüködnek a rájuk bízott diákok inklúziójának támogatásában. A kurzus terepe a baranyai hatókörrel müködö Faág Baráti Kör Egyesület már öt éve fogadja az érdeklődő hallgatókat pécsi közösségi házában. A hallgatók 20 órát töltenek el az intézményben óraadással, projektek szervezésével, kulturális és sport programok megvalósításával - megismerkedve eközben a gyermekvédelemben élő vagy családsegítő látókörébe került, cigány és nem cigány fiatalok élethelyzetével. Az öt év tapasztalata, hogy - a kezdeti félelmek ellenére - a hallgatók egy része „túlteljesíti” az elvárt óraszámot és rábízott feladatokat a kurzus során. Többen pedig a kurzus vége után is önkéntes munkát végeznek az egyesületben. A hallgatók a kurzus befejeztével egy személyes beszámolóban összegzik pedagógiai tapasztalataikat (szemelvényeket lásd a 2. számú mellékletben). A beszámolók- 
ból kiderül, hogy olyan pedagógiai helyzetekbe kerülnek e kurzuson a hallgatók, melyek bár nem mindennapiak, de láttatják a gyerekek hátteréből adódó sokféleséget. A gyakorlat során derül ki a hallgatók számára, hogy a pedagógusnak - a szaktárgyi tudáson túl - milyen sokrétüen kell ahhoz felkészültnek lennie, hogy valóban eredményes tudjon lenni a rábízott diákokkal.

További tereplehetőség a tanítási gyakorlatok különböző formáiban kínálkozik. Egyetemünk több olyan iskolával áll partnerintézményi kapcsolatban, ahol a különböző társadalmi helyzetü, kulturális hovatartozású és egyéni adottságú tanulók együttnevelése valódi inkluzív szemlélet és gyakorlat mentén zajlik. Legutóbb 2009 és 2011 között valósult meg az a projekt, mely során három megye (Baranya, Somogy, Tolna) településein - Kétújfalu, Báta és Darány - lévő iskolák készülttek fel arra, hogy hallgatók csoportos és egyéni tanítási gyakorlatához, illetve az összefüggő tanítási gyakorlatukhoz nyújtsanak terepet. A három iskola közös jellemzője, hogy nagy számban fogadnak hátrányos helyzetü, roma/cigány és sajátos nevelési igényü tanulót, akik inkluzív nevelésére modellprogramot alakítottak ki - az Országos Oktatási Integrációs Hálózat bázisintézményeiként.

\section{Sajátélmény az inklúzióról a felsőoktatásban}

Az inklúzió szemléletének a fentiekben részletezett kurzusokon történő hallgatói interiorizációja csakis akkor képzelhető el, ha maga a felsőoktatás is egyre inkluzívabbá válik. Ennek gyakorlati eszköze a formális és informális területeken kialakítandó együttmüködés. Fontos, hogy a hallgatók sajátélményként megéljék, hogy az inklúzió és a kooperativitás nem a közoktatás osztálytermeinek kizárólagos jellemzője, hanem minél több kontextusban értelmezendő: tanár-tanár, tanár-diák, diák-diák relációban is (Forray és Varga, 2011).

Mindezek végiggondolásához látnunk kell, hogy akkor beszélhetünk inklúziót eredményező kooperatív müködésről, ha egy-egy területről, helyzetről, müködésről bebizonyosodik, hogy a benne lévő szereplők tevékenységei nem végezhetők el sikeresen egymás nélkül (építő és ösztönző egymásrautaltság van közöttük), ha a feladatok egyidejüleg készülnek a résztvevők közös tevékenységeivel (párhuzamosan interakcióik során), ha minden bevont személy maga felel a munkájáért, és erről folyamatosan számot ad (az egyéni felelősségvállalás és számonkérés müködik), illetve ha biztosított, hogy mindenki egyenlően férjen hozzá az információkhoz, lehetőségekhez, és személyre szabottan vehessen részt a folyamatokban egyenlő részvétel és hozzáférés szemlélete szerint (Arató és Varga, 2006).

A felsőoktatást az előző elvrendszer mentén szemlélve megállapíthatjuk, hogy amennyiben a felsőoktatásban dolgozó tanárok úgy alakítják sokrétü tevékenységeiket, hogy közben szerves részei egy kooperatívan müködő szakmai csoportnak, akkor hatékonnyá, eredményessé és méltányossá válik a felsőoktatás valamennyi ott dolgozó számára. Egy másik viszonyrendszer a tanárok és diákok közötti együtt- 
müködés, mely ha az egyedi igények és szükségletek figyelembe vételén alapul, akkor olyan inkluzív rendszert eredményez, mely a diákokból a legtöbbet képes kihozni. További hozadéka, hogy képes a tudás interiorizációját a diákoknál elérni, és a tanár-diák kapcsolat nem csak egy rövid és kötelező időszak hatalmi befolyásolási szintjét éri el. A harmadik viszonyrendszerben (diák-diák) megfigyelhetö, hogy a hallgatók között legtöbb esetben müködik az a - tanulást is támogató - kooperatív háló, ami a tapasztalatok szerint az informális kapcsolataik egyik fó jellemzője. Tudnunk kell, hogy formális helyzetekben alapvetően a tanári kompetencián (attitűd-, ismeret- és képességrendszeren) múlik, hogy felerősödik-e a diákok közötti kooperáció vagy kiszorul az informális mezőkre. Ezzel egy időben a formális mezőben pedig az inklúzióval szemben a versengést vagy éppen az érdektelenséget generálja.

Az alábbiakban olyan tanulásszervezési példák következnek, melyek a kooperatív tanári attitüddel és mesterségbeli tudással a felsőoktatás formális terében is inkluzívvá tudják tenni a tanulási folyamatot.

Az inkluzív tanulási környezet alapegységeként elöször szükséges létrehozni a kooperatív csoportot. Vagyis egy adott kurzuson résztvevők körét kisebb egységekké, csoportokká szervezzük. A csoportok létrehozásakor több szempontot is figyelembe kell vennünk. Egyik legfontosabb elv, hogy a csoportok heterogén összetételüek legyenek a hozott tudás, a tématerülettel kapcsolatos kompetenciák, az életkor és a nem szempontjából. Amennyiben releváns, további szempont lehet a különböző kisebbségi csoportokhoz tartozás vagy a nyelvtudás. A hagyományos csoportalkotással szemben a kooperatív csoport esetén a tanár elöre tervezi, hogy a résztvevők mely csoportban fognak dolgozni - ezzel tudja biztosítani, hogy a csoportok biztosan heterogének legyenek. A tervezés kiinduló pontja, hogy a tanár alaposan megismerje diákjait, és erre építve alakítsa ki a heterogén csoportokat.

Az így létrehozott csoportok még nem állnak készen a közös munkára: elöször olyan közös tevékenységsoron kell végighaladniuk, melyek elsődleges célja a csoportfejlesztés. A fejlesztés kettős: individualizációs és csoportidentitási részekből áll. Ez azt jelenti, hogy a csoportba bevont egyén lehetőséget kap arra, hogy személyes tulajdonságait, tudását, elvárásait megossza társaival, a társai pedig egyéni feladatot és kooperatív szerepet bíznak rá. Mindezzel azt célozzuk, hogy mindenki érzékelje egyéni felelősségvállalását a közös munkában, azt a helyzetet, hogy a csoport segítő háttér a tanulási folyamatban. A csoport közösségének kialakítása mindezzel egy időben zajlik: együttes élményeken keresztül a csoporttagok maguk azonosítják csoportjukat együttmüködő közösségként. E fejlesztési folyamat fontos eleme, hogy a csoport-együttmüködés során kialakuló spontán csoportdinamikát irányított pedagógiai folyamatként az egyén személyes fejlesztésének szolgálatába állítjuk. Vagyis a csoporttagok az együttmüködés kezdetén olyan kooperatív szerepeket kapnak (vagy osztanak ki egymás között), amelyek segítik a csoport hatékony müködését. Így lesz, aki arra figyel, hogy mindenki a feladattal foglalkozzon, aki azt 
ellenőrzi, hogy minden írásos munka elkészült-e, aki beosztja a rendelkezésre álló időkeretet, és aki szervezi a csoporttagok egyenlő részvételét és hozzáférését. Ezek a szerepek spontán alakulnak ki egy együttmüködő közösségben úgy, hogy mindenki a legfejlettebb képességei szerint vállal feladatot. Ezzel szemben a kooperatív csoportban mindenki olyan szerepet kap és vállal, mely területen fejlesztésre szorul. Így az adott szerep müködése során lehetőség van hiányzó kompetenciái folyamatos és észrevétlen fejlődésére. A szerepek további funkciója, hogy a tanulási folyamattal kapcsolatos jogokat és kötelességeket (felelösséget) delegálják azok számára, akik a tanulási folyamat aktív szereplői. Ez alapvetően megváltoztatja a hagyományos tanárszerepet is: a kooperatív tanulásszervezés csoportjaiban szerepet betöltó diákok a tanár helyett maguk figyelnek arra, hogy mindannyian folyamatosan és interaktívan a feladattal foglalkozzanak. Ezzel elérhetö, hogy a tanulás ne csak a tanár számára legyen fontos: a diákok pozitív attitüdje az adott tématerülettel kapcsolatban interiorizálódik, és nem kizárólag a tanári hatalmi befolyásolás miatt foglalkoznak a tananyaggal.

A tanár által tervezett és fejlesztett csoportok ezt követően kaphatnak önálló feladatokat. Természetesen a legjobban kialakított és fejlesztett csoportok esetén is folyamatosan biztosítani kell a valódi kooperáció érvényesülését. Ennek támogatói a kooperatív struktúrák (Kagan, 2000), melyek a feladatok elvégzésének módját határozzák meg. A kooperatív struktúra olyan lépéssor, mely bármely tartalommal feltölthetö, és amely legföbb sajátossága, hogy a kooperatív alapelvek müködését biztosítja. A leginkább ismert és leggyakrabban - sokszor nem is tudatosan - használt struktúra a „mozaik” (jigsaw puzzle - Aronson, 1978, 2009). A mozaik lényege, hogy egy konkrét tananyagot bontunk részekre, és osztunk szét differenciáltan egy csoport tagjai között. Ezt követően fontos, hogy a kapott saját részt mindenki önállóan dolgozza fel, majd egyeztesse az azonos témán dolgozó más csoportok tagjaival. A feldolgozott és társak által pontosított tananyagrészt mindenki a csoporttagjainak megtanítja, és végül egyénileg ad számot a teljes tananyagról. Így müködik a személyes felelősségvállalás és számonkérés, hiszen van egyéni feladatrész, amit csak egy csoporttag tud, és neki kell a többiekkel megosztania. Érvényesülni tud az, egyenlő a részvétel és hozzáférés, mivel mindenki kap feladatot, de olyat, amit meg is tud oldani. Mindezt az építő egymásrautaltság is erősíti, vagyis csak akkor rakható össze a teljes tudás, ha a csoporttagok megosztják egymással a sajátjukat. A belsővé válást erősíti a résztvevői bevonódás, mely az egy időben párhuzamosan dolgozó csoportok interaktív kisközösségében érhető el.

Hasonló struktúrákat igen sokat ismerünk, és egy kooperatív tanulásszervezéssel dolgozó csoport számára a „használjuk a szóforgót”, „készítsünk ablakot”, „játsszunk egy füllentőst” vagy „ellenőrizzünk villantókártyával és kettős körrel” tanári utasítások nem bonyolultabbak, mintha az hangozna el, hogy „nyissuk ki a könyvet". 
Az a tanár, aki ilyen módon szervezi a tanulási folyamatot, egyúttal a kooperatív értékelésre is megtanítja a csoportot. Ez esetben a választóvonal nem a jeggyel vagy szöveggel történő értékelés között húzódik, hanem az egyéni-csoportos, a tanári-diák, a saját-mások értékelése lehetnek a visszajelzés területei. Ezeket az értékelési formákat felhasználjuk a diákok formális értékeléséhez is, de ennél sokkal több és jelentősebb az a visszajelzés - megerösítő és korrigáló funkciójú értékelés -, amelyet a csoport tagjai a folyamatos interakciók során egymásnak adnak. Hiszen a tudásszerzés kooperatív nyilvánossága arra készteti a diákokat, hogy bátran merjenek kérdezni, vállalni tudásukat és nem tudásukat. Egyúttal azt is elsajátítják, hogy úgy tudjanak a másik számára segítséget nyújtani, hogy az mindkettőjüknek jó érzés legyen, a kölcsönösség és nem a kiszolgáltatottság alapján. Vagyis valóban befogadók legyenek a kooperáció nyújtotta lehetőségek segítségével. A kooperatív szemlélet alapján dolgozó diákok elfelejtik azt a formális nevelés által kondicionált rendszert, melynek egyenes következménye egy olyan társas kapcsolat, ahol a „ne súgj” (ne segíts) és a „ne less” (ne kérj segítséget) az elvárás és alapérték. Itt nem a súgás, lesés tiltásáról van szó, hanem közös munkáról, egymás segítéséröl. A másik egyedi tulajdonságaira való értékként tekintésről, melynek természetes hozadéka az inkluzív szemlélet.

A felsőoktatásban, a katedráról talán még nehezebb a tanárnak elfogadni, hogy az inklúziót célzó kooperatív csoportokban zajló tanulási folyamat „főszereplője” a diák - minden szempontból. Azonban a leendő tanárjelöltek csak akkor tudják valóban képviselni az inklúzió szemléletét és gyakorlatát, ha erről sajátélményt szereznek - a felsőoktatás falai között is.

\section{Irodalom}

Arató Ferenc, Varga Aranka (2006): Együtt-tanulók kézikönyve. PTE BTK NTI, Pécs.

Aronson, E. (1978): The Jigsaw Classroom. Sage Publications Inc. www.jigsaw.org

Aronson, E. (2009): Columbine után. AB OVO Kiadó, Budapest.

Bárdossy Ildikó, Dudás Margit, Pethőné Nagy Csilla, Priskinné Rizner Erika (2003): Kooperatív pedagógiai stratégiák az iskolában IV. PTE BTK Tanárképző Intézet, Pécs.

Forray R. Katalin, Varga Aranka (2011): Inklízió a felsőoktatásban. Pécsi Tudományegyetem Bölcsészettudományi Kar. Letöltés ideje: 2012. március 6.

http://webcache.googleusercontent.com/search?q=cache:DDOceE_6gzYJ:janus.ttk.pte.hu/ tamop/tananyagok/inkluzio_a_felsooktatasban/index.html+\&cd=1\&hl=hu\&ct $=$ clnk $\& \mathrm{gl}=\mathrm{hu}$

Kagan, S. (2000): Kooperativ tanulás. Önkonet, Budapest.

Potts, P. [ed.] (2003): Inclusion in the City: A Study of Inclusive Education in an Urban Setting. Routledge Falmer, London, New York.

Réthy Endréné (2004): Inkluzív pedagógia. In: Nahalka István - Torgyik Judit (szerk.): Megközelitések - Roma gyerekek nevelésének egyes kérdései. Eötvös József Könyvkiadó, Budapest, 231-246. 
Varga Aranka (2006): Multikulturalizmus - inkluzív oktatási rendszer. In: Forray R. Katalin (szerk.): Alapismeretek a romológia asszisztens képzéshez. PTE BTK Romológia és Nevelésszociológia Tanszék, 145-161. Letöltés ideje: 2012. március 6. http://mek.niif.hu/04800/04867/04867.pdf

Varga Aranka (2010): Inkluzív társadalom és iskola. In: Varga Aranka (szerk.): Esélyegyenlőség a felsőoktatásban 1. PTE BTK NTI Romológia és Nevelésszociológia Tanszék, Pécs. Letöltés ideje: 2012. március 23. www.wlislocki.pte

Várnagy Elemér, Várnagy Péter (2000): A hátrányos helyzet pedagógiája. Corvinus Kiadó, Budapest.

Vastagh Zoltán (1999): Kooperativ pedagógiai stratégiák az iskolában III. JPTE Tanárképző Intézet, Pécs.

\section{MELLÉKLET}

1. számú melléklet: Az Inkluzív pedagógia kurzus célja és eredménye egy kérdőíves felmérés alapján

\begin{tabular}{|c|c|}
\hline $\begin{array}{c}\text { A kurzus } \\
\text { - akkreditációban is szereplö- } \\
\text { céljai }\end{array}$ & $\begin{array}{c}\text { A hallgatói visszajelzésekböl látható eredmény }{ }^{1} \\
\text { (Azt tanultam...) }\end{array}$ \\
\hline $\begin{array}{l}\text { A hallgatók szerezzenek } \\
\text { konkrét ismereteket } \\
\text { a kooperatív tanulásszervezésről, } \\
\text { mint az inklúzió gyakorlati } \\
\text { eszközéről. Az ismeretszerzés } \\
\text { sajátélményü tanulás } \\
\text { segítségével történjen, és } \\
\text { legyen lehetőségük } \\
\text { a résztvevőknek tanári } \\
\text { kompetenciáik bővítésére is } \\
\text { ezen a területen. }\end{array}$ & $\begin{array}{l}\text { „miként illesszem be a kooperáció/differenciálás } \\
\text { eszközével a különböző gyerekeket egy csoportba.” } \\
\text { „hogyan szervezzem, milyen szempontokat tartsak szem } \\
\text { elött a tanulás megtervezésekor, hogy minden gyerek } \\
\text { egyénileg is tanuljon.” } \\
\text { „sokkal motiváltabbak a diákok az aktív részvétel és } \\
\text { az egyéni vélemény-kifejtés segítségével.” } \\
\text { „az egyéni igények mentén kell alakítani a tanulási } \\
\text { folyamatot.” } \\
\text { „a tanár a tanulási folyamat irányítója és nem a tudás } \\
\text { forrása.” } \\
\text { „stratégiát, hogy hogyan szervezzek egy kooperatív órát.” } \\
\text { „együtt vagyunk erősek, illetve akkor nyerek, ha másik } \\
\text { is nyer.” }\end{array}$ \\
\hline
\end{tabular}

\footnotetext{
${ }^{1}$ Az önkéntes, önkitöltős és név nélkül készülő kérdőív két nyitott mondat befejezését várta a kurzus végén a részt vevő hallgatótól. A nyitott mondatok:

1. Azt tanultam a kooperatív tanulásszervezésröl, mint az inklúzió eszközéröl, hogy...

2. Azt tanultam a különbözö társadalmi helyzetü, kulturális hovatartozású és egyéni adottságú diákokról, mint az inkluzív pedagógia érintettjeiröl, hogy...
} 


\begin{tabular}{|c|c|}
\hline $\begin{array}{c}\text { A kurzus } \\
\text { - akkreditációban is szereplö- } \\
\text { céljai }\end{array}$ & $\begin{array}{c}\text { A hallgatói visszajelzésekböl látható eredmény }{ }^{1} \\
\text { (Azt tanultam ...) }\end{array}$ \\
\hline $\begin{array}{l}\text { A hallgatók ismerjék meg } \\
\text { a sokszínü társadalomban } \\
\text { megjelenő együttélési } \\
\text { stratégiákat: az asszimiláció, } \\
\text { szeparáció, szegregáció, } \\
\text { integráció, inklúzió müködési } \\
\text { mechanizmusait. Dolgozzák fel } \\
\text { az inkluzív társadalom és iskola } \\
\text { heterogén világában megjelenő } \\
\text { egyének és csoportok } \\
\text { sajátosságait - különös } \\
\text { tekintettel a társadalmilag } \\
\text { hátrányos helyzetre és } \\
\text { a magyarországi cigányságra. } \\
\text { Szerezzenek sajátélményt } \\
\text { a különböző társadalmi helyzetü, } \\
\text { kulturális hovatartozású és } \\
\text { egyéni adottságú tanulók } \\
\text { jellemzőiről. }\end{array}$ & $\begin{array}{l}\text { „Megerösítette azt a nézetemet, hogy szükséges } \\
\text { a különböző gyerekek integrálása, a szegregáció csak } \\
\text { ront a helyzetükön.” } \\
\text { „Eszköztárat mutatott az óra az inklúzióra, különösen } \\
\text { a cigány kisebbséggel kapcsolatban.” } \\
\text { „Senkiröl sem szabad lemondani.” } \\
\text { „A különböző gyerekek kimeríthetetlen eröforrások.” } \\
\text { „A hátrányos helyzetü és cigány csoportokban élök } \\
\text { helyzetét mi is átérezhettük.” } \\
\text { „Fontos a hátrányos helyzetűek inklúziója, hogy } \\
\text { megadjuk nekik az esélyt. Erre vannak szakmai } \\
\text { módszerek.” } \\
\text { „Hátrányos helyzet mibenlétét.” } \\
\text { „Ne kategóriákba soroljuk az embereket, hanem } \\
\text { egyénekkel foglalkozzunk.” } \\
\text { „Vannak csoportok kulturális sajátosságokkal.” } \\
\text { „A cigány kisebbséget nem kell azonosítani } \\
\text { a társadalmilag hátrányos helyzetü csoporttal.” }\end{array}$ \\
\hline
\end{tabular}

2. számú melléklet: Részletek hallgatói beszámolókból, melyek az „Inkluzív pedagógia speciális kollégium” zárására készültek

\begin{tabular}{|c|c|}
\hline Bevezetö gondolatok & Összegzések \\
\hline $\begin{array}{l}\text { „Korábban még nem találkoztam az } \\
\text { egyesület nevével, de az első órán } \\
\text { elhangzottak nagyon tetszettek. Maga } \\
\text { a tény azonban nagyon is megrémített, } \\
\text { hogy én, aki gyereket csak a hospitálás } \\
\text { közben a hátsó sorból láttam, rögtön } \\
\text { bekerülök egy a hátrányos helyzetü } \\
\text { gyerekek életét megkönnyítő egyesület } \\
\text { munkájába.” L. K. }\end{array}$ & $\begin{array}{l}\text { „Mivel az utolsó pillanatban kaptam egy új } \\
\text { diákot, úgy döntöttem, hogy a ,hivatalos’ } \\
\text { óráim lejárta után is bejárok korrepetálni, } \\
\text { kíváncsi vagyok, mennyire tudom } \\
\text { hasznosítani az egyetem alatt tanult } \\
\text { didaktikai módszereket és alaptéziseket egy } \\
\text { olyan közösségben, amelynek nem ,átlagos' } \\
\text { gyerekek a tagjai.” L. K. }\end{array}$ \\
\hline
\end{tabular}




\begin{tabular}{|c|c|}
\hline Bevezetö go & zések \\
\hline $\begin{array}{l}\text { „A FAÁG Egyesületről ezen a kurzuson } \\
\text { hallottam elöször. Korábban nem tudtam } \\
\text { róla, hogy van egy ilyen szervezet, amely } \\
\text { a roma gyerekek megsegítését tüzte ki } \\
\text { céljául, hogy segítsen nekik felzárkózni } \\
\text { az iskolában. Tehát az első információimat } \\
\text { a szervezetröl az első órán szereztem, és } \\
\text { szó mi szó, nem voltam elragadtatva az } \\
\text { ötlettől, hogy a gyakorlatomat egy olyan } \\
\text { helyen kell eltöltsem, ahol a gyerek } \\
\text { gondol egyet és lehet kiugrik az ablakon.” } \\
\text { B. E. }\end{array}$ & $\begin{array}{l}\text { „Az ebéd jól sikerült, mindenkinek ízlett, és } \\
\text { miután mindenki jóllakott, elrámoltuk az } \\
\text { edényeket. Ezen a rendezvényen már sokkal } \\
\text { jobban éreztem magam, mint a legelső } \\
\text { alkalomkor, amikor a FAÁG-ban jártam, így, } \\
\text { hogy tele volt a ház gyerekekkel minden } \\
\text { sokkal barátságosabb volt. Egy-két gyerekre } \\
\text { azt hiszem, még sokáig emlékezni fogok, } \\
\text { pl. a Janikára, aki egy tündéri kisgyerek, vagy } \\
\text { a Dzseni-re, aki nagyon eleven.” B. E. }\end{array}$ \\
\hline $\begin{array}{l}\text { „Az Faág Baráti Körbe még az első } \\
\text { kurzus-megbeszélés után ellátogattam } \\
\text { egyik csoporttársammal, aki szintén } \\
\text { a kurzusra jár. A megbeszélés - bár érdekes } \\
\text { előző félévi tapasztalatokra is fény derült } \\
\text { - ugyan nem rettentett el minket } \\
\text { a gyakorlattól, mégis mindketten úgy } \\
\text { éreztük, hogy jobb, ha nem egyedül } \\
\text { megyünk első alkalommal.” T. Z. }\end{array}$ & $\begin{array}{l}\text { Mondandómat összegezve, letisztítva, az } \\
\text { a véleményem, hogy a Faág egyesület egy } \\
\text { nagyon jó hely... Az eddig ott gyakorlattal } \\
\text { eltöltött időt nagyon élveztem, és tényleg } \\
\text { megváltozott az első benyomásom a hellyel } \\
\text { kapcsolatban, szeretnék a továbbiakban, } \\
\text { gyakorlatom befejezése után is időnként } \\
\text { benézni, és segíteni, ha tudok.” T. Z. }\end{array}$ \\
\hline $\begin{array}{l}\text { „Nekem - sokakkal ellentétben - nem } \\
\text { voltak félelmeim az első találkozás } \\
\text { élményétől, annyit sejtettem, hogy ,más’ } \\
\text { lesz, mint az eddigi tapasztalataim, ezalatt } \\
\text { itt azokra az iskolákra gondolok, ahol } \\
\text { hospitálni voltam, illetve a tanítási } \\
\text { gyakorlatot is ebben a félévben a faági } \\
\text { látogatásokkal együtt, párhuzamosan } \\
\text { végeztem.” P. D. }\end{array}$ & $\begin{array}{l}\text { „Összességében az első benyomásom } \\
\text { abszolút pozitív volt, a gyerekek nagyon } \\
\text { kedvesek, segítőkészek voltak velem, lehet } \\
\text { kicsit ,egyszerübbek’ mint mások, de } \\
\text { legfontosabb a jó tulajdonsággal rendelkező } \\
\text { emberek. És az van bennük bőven.” P. D. }\end{array}$ \\
\hline
\end{tabular}




\begin{tabular}{|c|c|}
\hline Bevezetö gondolatok & Összegzések \\
\hline $\begin{array}{l}\text { „Amikor felvettem ezt a kurzust, } \\
\text { fogalmam sem volt, mit takar a „speciális } \\
\text { kollégium” elnevezés. A ,kollégium’ szó } \\
\text { alapján azt gondoltam, hogy megjelenünk } \\
\text { minden kedden a megadott időpontban és } \\
\text { teremben, és a szokásos kurzuskeretek } \\
\text { között hallhatunk újabb elméleteket arról, } \\
\text { hogy milyen típusú diákok léteznek és } \\
\text { nekünk, leendő pedagógusoknak hogyan } \\
\text { is kellene őket tanítanunk, a problémákat } \\
\text { kezelnünk. Meglepődtem, amikor az első } \\
\text { alkalommal megtudtam, hogy most } \\
\text { egyáltalán nem erröl van szó, hanem egy } \\
\text { abszolút gyakorlati teljesítésröl. Mivel } \\
\text { még nem voltam tanítási gyakorlaton, } \\
\text { először egy kicsit elbizonytalanodtam, } \\
\text { hogy bevállaljam-e azt, hogy bárkit is } \\
\text { tanítsak. Főként, amikor meghallottam } \\
\text { olyan kulcsszavakat, mint ,hátrányos } \\
\text { helyzet' vagy ,problémás gyerek'. Hogyan } \\
\text { foglalkozhatnék én ilyen gyerekekkel, } \\
\text { mikor még pedagógusként semmilyen } \\
\text { gyerekkel nem szembesültem? Bevallom, } \\
\text { úgy éreztem, hogy ,egyből a mély vízbe } \\
\text { kell ugranom’. Aztán úgy döntöttem; lesz, } \\
\text { ami lesz, én teljesítem ezt a kurzust és így } \\
\text { utólag elmondhatom, hogy egyáltalán nem } \\
\text { bántam meg azt az,fejest’.” I. T. }\end{array}$ & $\begin{array}{l}\text { „Összességében nagyon jól éreztem magam } \\
\text { a Faágban az elmúlt pár hét során. Egyrészt } \\
\text { örülök, hogy létezik egy ilyen szervezet, és } \\
\text { hogy egy kicsit én is kivehettem a részem } \\
\text { a munkájából, bepillantást nyerhettem } \\
\text { működésébe. Másrészt nagyszerü embereket } \\
\text { ismerhettem meg, felnőtteket és gyermekeket } \\
\text { egyaránt. Ez a velük töltött kis idő segített } \\
\text { ráébredni arra, hogy ezekben a gyerekekben } \\
\text { mennyi szeretet és sajnos fájdalom is lakozik, } \\
\text { mennyi problémával kell napról napra } \\
\text { megküzdeniük. Ráébredni arra, hogy én } \\
\text { mennyire szerencsés vagyok, hogy egy } \\
\text { átlagos családban nőhettem fel, és most } \\
\text { egyetemre járhatok. A pedagógusok } \\
\text { valószínüleg sokszor csak rendetlennek, } \\
\text { butának tekintik ezeket a gyerekeket, hiszen } \\
\text { az iskolában töltött idő általában nem } \\
\text { elegendő ahhoz, hogy közelebbröl } \\
\text { megismerjék őket és problémáikat, vagy } \\
\text { sajnos nem is érdekli őket. Úgy érzem, ez } \\
\text { a Faágban töltött kis idő segítséget nyújtott } \\
\text { nekem ahhoz, hogy pedagógusként én majd } \\
\text { ne így kezeljem a hozzájuk hasonló } \\
\text { gyerekeket.” I. T. }\end{array}$ \\
\hline
\end{tabular}

